\title{
Presentation of the research program The Intimization of Journalism
}

\author{
Transformations of Medialized Public Spheres \\ from the 1880s to Current Times
}

Anja Hirdman, Madeleine Kleberg \& Kristina Widestedt

The primary purpose of the project is to study what is included in and excluded from the medialized public spheres at different points of time during the period of 1885 through 2005, with particular focus on themes and issues related to family, sexuality and "the private".

A tendency towards increased media attention to these subjects in the late twentieth century has been widely noted. Some researchers see it as trivialization, feminization or tabloidization, whereas others prefer to talk about democratization and popularization, stressing the broadening of public discussions to include issues previously not debated and the inclusion of heretofore marginalized groups. We, for our part, have chosen the phrase "the intimization of journalism" to describe this process.

This intimization of journalism is conceived of here as a continuous process, closely related to the development of a mass circulation press and modern journalistic practices in the 1880 s, when the interview as a working method and the use of photographic pictures became increasingly important in journalism, in Sweden and abroad.

Contemporary media output is heavily sexualized overall, i.e., private issues are more and more directed towards sexual intimacy. One important question arises: Might this pervasive sexualization in the media actually undermine the originally de-

Anja Hirdman, Ph.D., Madeleine Kleberg, Ph.D., Kristina Widestedt, Ph.D., Senior Lecturers at Department of Journalism, Media and Communication, Stockholm University, P.O. Box 27861, SE11593 Stockholm, hirdman@jmk.su.se, kleberg@ jmk.su.se,widestedt@jmk.su.se mocratizing potential of representing and debtating private issues in the mediated public sphere?

The project is concerned with media representations and constructions of the intimate sphere, as well as with intimacy as a manner of addressing the media audience.

The empirical material includes newspapers and magazines of two early periods, i.e., the years around 1885 and 1925. Other chosen periods are the years around 1935, when radio will be included in the analyses, and 1965, 1980 and 2000, when television is included, as well.

The chosen periods capture significant changes in journalism as well as in society - changes which raise questions about boundaries between the intimate sphere and the public. Discursive methods are used in the analyses of the journalistic texts including images.

\section{Introduction}

The Intimization of Journalism is a program in the field of journalism and media research that considers the public sphere discourses of intimacy in a historical perspective. What is considered intimate is, like the concept of "private life", closely related to how the public sphere is constructeed. But, whereas "private" can be defined in spatial terms, as a place apart from public arenas, "intimate" is more complex. Intimacy is a fluid and, we find, historically metamorphic category that includes elements of identity and sexuality and, in the case of journalism, a position vis-à-vis the public and sources. It is in the public sphere that intimacy is defined.

As we conceive of it, intimacy is both a place within private life, the home (the intimate sphere) and an act constituted by social relations and a form 
of medial address. A similar dichotomy applies to our concept of what is "public", as well: the public sphere is at once a place - plazas, parks, shopping malls, theatres - and an act that includes elements of journalism and publicity, stat ements intended for public consumption, and political praxis. That is to say, we conceive of "intimacy", as opposed to "privateness", as including social interactions. Consequently, we have chosen to contrast the intimate sphere (rather than the private sphere) with the public sphere; both are constituted by communicative social relations. The medialized public sphere is seen to consist of different arenas defined in time and space (different media), where the definition and use of intimacy occurs and takes place.

The program is indebted in large part to feminist and gender theory. We consider it important to view the concept of gender in relation to issues concerning the different kinds of power over discourses and problem formulation that are at stake in the medialized public sphere. Gender relations, and definitions of them, are an ongoing process, and it is interesting to see which representations of these relations have been in currency at different points in time. This approach makes femininity and masculinity accessible to analysis as historical and medial categories.

\section{Aims and Background}

In theoretical terms, the aim of the research program is to define certain starting points for a historic/thematic discourse analysis of the transformations of the medialized public sphere, with particular attention to gender. Empirically, the program aims to cast light on the manners in which issues and phenomena that may be ascribed to the intimate sphere are treated (or ignored) by mass media at different points in time, and to explore the reasons for differences noted over time. It is our ambition to integrate theories of gender and the media in a systematic fashion, with a view to heightening awareness of the prevailing gender order within journalism. We believe that our shift of focus from the public to the intimate sphere, combined with an ambition to found the theories in an empirical and longitudinal material, has the potential both to make a contribution to theory and to improve our understanding of an important area of human activity.

In theories concerning the demarcation between the intimate and the public spheres, phenomena relating to mass media are generally assigned to the public sphere. Media do, after all, have to do with publicity; they shape the public sphere, filling it with material about society, public life and the private sphere. At the same time, much of the material relates to so-called private matters - according to Habermas' classical dichotomy, whereby the intimate sphere concerns "hearth and home" and reproduction, and the public sphere, political, economic and societal issues (Habermas 1988).

Thus, a media and journalism research perspective implies the formulation of a more flexible demarcation of private versus public inasmuch as the media, starting in their more institutionalized mass production phase (around 1880), have interwoven the private and the public spheres, mixing the intimate with the public. This is particularly true of content (a focus on everyday life), but also narrative form (the address, use of illustrations/photos). Rather few theories of the public sector involve media; those that do apply for the most part Habermas' conceptual structure, viz., that media are discussed in terms of how they relate to other kinds of public spheres (the bourgeois in Habermas' case), without taking account of the medialized public sphere itself as a specific kind of publicity or "publicness". Interesting in this regard is precisely the quality of this medialized public sphere, in which the private, the intimate, is used and defined (cf. Fraser 1992, Landes 1998).

\section{Intimization}

That growing focus on "private life", on the intimate sphere, that is seen to characterize media content since the final years of the past century has been branded by some media scholars as a trivialization, vulgarization or tabloidization of the media (cf. Blumler \& Gurevitch 1995, Sparks \& Tulloch 2000 , i.a.), whereas others consider it rather a democratization or popularization of the media, as issues, subjects and groups of people that previously were excluded are now discussed and heard and seen (cf. Livingstone \& Lunt 1994, Thompson 1995 , Hartley 1996, McLaughlin 1998, i.a.).

These quite divergent assessments have given rise to recurrent debates on the implications of the changes in journalism. Currently, the issue of tabloidization is among the most widely debated. The term itself has been used in at least three different senses in the literature (cf. Sparks 2000).

1. as a descriptor of a change in news journalism overall, whereby amusement displaces serious news journalism. Tabloidization, according to this definition, has two main characteristics: 
- less interest in politics, economics and public affairs, but more attention to sports, scandal and popular entertainment; and

- considerable interest in "private life" and the personal sphere, whether or not the individuals are so-called media personalities, and less interest in political processes, economic development and social change.

This perspective has to do with the boundaries between journalism and other media content and raises the question of whether or not tabloidization poses a threat to democracy.

2. as a descriptor of a shift in priorities within a given medium from news and information toward entertainment. Public service television in new, commercially dominated multichannel systems is a prime example of this. This discussion raises the question of the balance between news and entertainment.

3. as a descriptor of changes in taste within various genres (the editorial content itself). Journalism is impacted in several ways when political discussions are displaced by talk shows, where ordinary people (non-experts) talk about their personal experiences and problems. Here the question is about the standards of public debate and how much of the intimate sphere should be made public.

Attitudes toward tabloid journalism have become indicators of broader political standpoints or positions: apologists brand critics of the tabloids for their conservative elitism with respect to news and democracy and say the critics neglect popular interests when they do not take the tabloids seriously. More extreme apologists look upon tabloid newspapers as the bastion of common folks' resistance to the powers that be, as a realm in which alternative worldviews, meanings and interpretations are produced. Tabloid news may very well treat the same topics as the elite news treats, but it approaches the topics from a distinctly different perspective (a focus on individuals) and using a different idiom (everyday language and a tone of intimacy). This is not simply trivializing and negative; it may indeed be seen as a form of democratization. Thus, the tabloids, viewed from this point of view, are essentially subversive of the social order.

Judgments of tabloids readily extend themselves to judgments of those who read them, which implies a problem of legitimacy. The simplest interpretative schema results in a dichotomy: serious media are for the upper classes, and popular media for the lower classes - or, democracy is the concern of an elite, whereas the masses are satisfied with entertainment. Which is to say, in so many words, that the masses have abdicated from the democratic process in order to devote themselves to things personal and private, while a (wealthy, well educated and male) responsible elite minority keep democracy afloat by participating in "public affairs".

Confronted with empirical fact, however, such a view proves untenable. Serious journalism need is of course not restricted to the rich, the well educated or the powerful. Public service radio and television have, for example, supplied the entire Swedish people with serious news and current events programming the greater part of the past century. There is, however, a certain risk that the multichannel system of today may result in a social stratification within the fragmented audiences of broadcast media, like that we find among readers of newspapers. Nor should we neglect the long and historically influential press traditions of the labor movement, which struggled to create a serious alternative to the news carried by the bourgeois press so as to bring enlightenment to general readers. The party press was driven more by ideological than by commercial motives and devoted a great deal of attention to social issues that were deemed to be of universal interest.

Rather little research on the transformations of the past couple of decades has considered their historical background in any extended longitudinal, empirical perspective (with the exception of, for example, Esser 1999; see also Thompson 1995). Having an ambition to develop new approaches to the subject, we have chosen to describe the changes in terms of medial representations of the intimate sphere. We are interested in how the intimate becomes part of the medialized public sphere, and how the medialized public sphere is made intimate.

Characteristic of the "intimization of journalism" perspective is that modes of address, relations to sources, visual representations, and the focus of the texts are seen to interact to create a kind of medial pseudo-intimacy. Thompson (Ibid.) speaks of mediated quasi-interaction, a close, but not identical concept that solely concerns reception, whereas the concept of medial pseudo-intimacy involves all the links in the communicative chain: production, text and reception. Thus, our use of the concept of intimization of journalism reflects our ambition to encompass the central points of conflict between the private sphere and the public sphere as well as the dual communication with sources and audiences/ readers that characterizes journalism. That is why 
we choose not to speak of tabloidization, with the inherent risk of getting mired down in the barren, polarized debate that has surrounded that subject to date. As we see it, the term "intimization of journalism" may be used to describe different aspects of the medial transformations of the twentieth century without implying any valuations of them.

\section{Analytical Perspective}

A growing share of what was once seen to belong to the intimate sphere has over time come to be discussed in both political and medial arenas. In the course of this process of transformation, "the public interest" has often been weighed against issues of individuals' and families' integrity or, as it is sometimes referred to, "the sanctity of hearth and home". Both "the public interest" and individuals' right to privacy are focal in journalism ethics. The concepts are also largely interpreted within the institution of journalism, and are thus inflected by factors relating to the media such as editorial processes, journalists' routines for gathering and reporting information, and so-called media logic. In concrete terms this means that the bounds of ethically defensible publication are relative, not absolute, and will vary over time. Since issues of ethics often concern publication of information belonging to the intimate sphere, codes of ethics are important in the research program.

Otherwise, three more general perspectives have guided our analysis of the transformations of the medialized public sphere. One of these we have dubbed "medialized public intimacy". In this perspective, journalism uses and defines the intimate in the framework of a prescriptive or didactic discourse. We believe that journalism has always done this, but it has taken different forms of expressions over time. Discourses and advice relating to both details of daily life and norm-laden identifying "tags" in the representation of various groups are typical of several journalistic genres. The production of images and texts about private life, which may be regarded as a form of publicizing of the intimate, is a recurrent theme in the medialized public sphere.

Recent years have seen a marked sexualization of media output. Two trends are at play: a sexualization of media content, and a sexualization of audiences and readers. The former implies that issues relating to the private sphere become increasingly sexually intimate. An important question is which groups figure in the sexualized media output. In the case of the sexualization of media consumers, we see how techniques of intimacy, like the so-called "human touch" perspective and identification-eliciting themes increasingly categorize viewers and readers and address them as primarily sexual beings.

The term, "sexualization" means that someone or something is ascribed a meaning that culturally (and historically) has sexual connotations. By definition, this approaches a pornographic form of expression. The project will not explore hard core pornography, but will rather delineate the cultural process whereby a pornographic aesthetics is accorded greater space in journalistic output.

Another perspective is "the political public interest of the medialized intimate sphere". Judgments as to what lies within the realm of "public interest", and what is "a private nature" is hardly, as the term may suggest, absolute or eternal. Where the boundary runs between private and public depends on who has the power to decide what is to be discussed (or not) and the terms on which the discussion takes place.

It is widely held that certain issues should not be discussed in public, and an important limit on public conversation is the notion that neutrality should be observed on issues relating to "the good life" and to morality, religion or taste. No one should claim that his or her views on these issues is more valid than others' views. As a consequence, these subjects are relegated to private conversation. This liberal or "legalistic" model revolves around the premise of a "just and stable public order" (Benhabib 1992). Theories of the public sphere, whether they are based on legalistic or discursive models, are mostly normative; rather few are based on empirical study (Ibid.). The question has been raised, for example, whether Jürgen Habermas' discursive theory of the public sphere actually describes a historical reality, or rather consists of a set of unrealized ideals (cf., for example, Gripsrud 1999). From feminist points of view, Habermas' theory has been criticized for positing the dichotomy of public versus private, which is seen to place it in a discourse that legitimizes the exploitation of women and the oppression of women in the family sphere (see, for example, Fraser 1995).

That some issues are banished from public debate and privatized means, in other words, that matters of urgency to certain groups are not broached as topics for public discussion. Democratization of the public sphere demands, feminists contend, that the inequalities of gender relations in the intimate sphere be discussed in public. This is also a neglected topic in media research, which has long been open to criticism for its preoccupation 
with news relating to the "hard core" of the public affairs (cf. Kleberg 1987, Halonen 1990, Dahlgren 1994). Abortion, prostitution, pornography, and domestic violence may be seen as paradoxical examples of issues that have been banned from public discussion because they were seen to belong to "the good life" and, consequently, not to public policy and issues of justice and equality. In other words, the lay of the boundary between what is to be considered public and private, respectively, is not gender-neutral.

A third perspective consists of what we call "intimized medial publicity". This type of intimization has to do with the manner in which journalism refers to its audiences and readers (journalistic address), but also with the intimacy of relations to sources.

The successive introduction of the journalistic interview toward the end of the nineteenth century represented a major departure from the courteous, not to say servile, attitude journalists had previously shown "public figures" (Schiller 1981, Schudson 1994). The conversational form and use of the inherent intimacy of the tête-à-tête enabled journalists to informalize their gathering of information; they came closer to the other party, both physically and psychologically. That interviews can be aggressive, embarrassing, even invasive (see, for example, Clayman 2002), is common knowledge. (Tellingly, in Swedish, the object of an interview perhaps we might say "the quarry" - is still called a "victim".)

Another aspect of the interview has to do with the intimacy that the conversational situation gives rise to between the interlocutors. It is not simply a case of the object of the interview being "lured" into a pseudo-intimate situation that causes him or her to speak freely, from the heart. The journalist, too, is influenced by the nature of the situation, which can seriously impact on the journalistic task at hand, should familiarity be allowed to develop too far.

The interview is the most commonly used technique among journalists today. It is so commonplace that the method itself is seldom questioned or problematized. What power relations are at play in the interview situation? What categories or groups are favored or put at a disadvantage? Do these aspects exhibit any patterns? Are elite individuals treated the same as "the man on the street"? Are men and women treated differently in any respect?

The program intends to examine the practice of the interview in different genres of journalism over an extended period, using case studies chosen primarily according to contextual factors, such as sig- nificant events or changes in the Swedish political or cultural public sphere.

Illustrations and photographs - traditionally referred to in the newspaper trade as "art" - have been prime tools for establishing a personal tone ever since they first made their appearance in the mass press. Since the 1880 s, photographs have slowly but surely supplanted illustrations. Images were used to reach a broader segment of the general public, people who responded to the emotional stimulus and "eye-witness" documentation that pictures (better than words) could provide. Pictures of people gave stories substance, literally personifying the stories newspapers told. Early on, pictures mainly took the form of "talking heads", the dead-pan, full-face representation of the public personage (Hirdman 2000). A trend toward informalization of press art got under way in the 1920s; by the 1930s, many of today's conventions of photojournalism had been established. New technology made the snapshot possible, dispensing with the pose. Subjectivity (involvement), action and "presence" are some of the ideals striven for today.

The projects in the program, The Intimization of Journalism, focus particularly on pictures of people, which represent one of the largest categories of pictures. The category includes portraits and news photos of public figures participating in conferences, etc., as well as in more private contexts. Journalistic pictures exert a profound influence on our perceptions of private and public depictions of individuals and events. Often, a picture can bridge the gap between the public and the private or define the private as visually separated from the public. On this level, pictures link individuals' private life with the public sphere and afford a kind of bridge from the public to the private. A common convention in the media is, for example, the technique of metonymy, i.e., letting one or two ordinary people represent a large social event or process, e.g., a new law, a rise in taxes. The advent of television reinforced already established visual conventions regarding the depiction of people, and new ones have been added. Visual depictions of individuals on television, relating either to the intimate or the public sphere, have differed over the years. The metamorphosis can in turn be understood as reflecting changes in the relationship between what is private and what is public.

Pictures of people also give rise to and reinforce readers' and viewers' impression of a social situation, as do interviews. Characteristic of photography and the television medium alike is their ability to create an illusion of nearness, of presence. The 
visual record of a "real" encounter augments the personal address. An interview is more than a conversation between two people; it is a whole situation that has to be documented, both verbally and visually, not least to permit the reconstruction of some form of communication with the media audience as the invisible, but ever present third party to the conversation. This is the reason for the recurring frontal pictures of speakers or listeners, who try to communicate with the audience via the lens of the camera. Here the media may be said to visualize the process of journalistic intimization.

\section{The Intimate Sphere and its Contexts}

We deal with the intimate sphere in terms of two categories: family and sexuality. While totally artificial, the dichotomy is justifiable as an analytical strategy. Most of the phenomena that fall into both categories are more separate in some periods than in others, depending on the prevailing norms and values in society. As an institution the family has changed continuously over the course of our period of study, albeit hetero normativity still largely steers our notions of the family. Sexuality was long a subject that the media mainly discussed in the context of married life (Hirdman 2002).

Researchers like Fraser (1997) and Pateman (1988) have been critical of research on the publicprivate dichotomy for paying too much attention to social issues at the expense of issues relating to the conditions surrounding sexuality. If, on the one hand, there may be political reasons to examine conditions (or abuses) in the intimate sphere, there are also personal reasons to defend the privateness of the intimate sphere and people's personal integrity and autonomy, as long as its exercise is not harmful to anyone else. Privateness may be seen to be both a challenge and useful when it is understood as a political value that allows personal development and emancipation (Boling 1996:31). The notion of "the sanctity of hearth and home" is once again of interest in this regard in relation to the medialized public sector. Some findings (e.g., Kleberg \& Widestedt 2002) suggest that women's private lives figure more frequently in the media than men's do, and that details of women's private lives are more often used against them when they figure in controversies or "scandals" having to do with their professional lives. Thus, the media would seem to be reluctant to represent women in other contexts than the intimate sphere - it is the intimate sphere, one might say, that defines women in the media.

\section{Empirical Considerations}

We have delimited our focus by

- concentrating on discursive events and using media themselves as the material for analysis, rather than as sources;

- studying the media material as a system of texts arising out of specific discursive frameworks; form and content are interpreted in a constructionist perspective, whereas intentionality and auteurism are accorded only secondary importance;

- applying a gender perspective to the material and its narratives rather than combing through the media for biographies of women.

As scholars in the field of the media and journalism we feel that it is both interesting and beneficial to our discipline to study journalism as a coherent system of media, genres and forms of expression. For that reason we choose to gather material from the daily press (including tabloids), magazines, and the broadcast media. We will include both hard news and interviews on serious subjects and lighter material in the form of human interest stories, interviews with media "personalities" and amusements. We include both verbal and visual representations of interview situations, with particular attention to the interplay of word and picture (still or motion).

Images in the media can never be properly understood apart from its relation to the text. In a study of the intimization process like the present program, it is therefore interesting to examine the relationship between pictures and words with a view to determining the message created by the visual-verbal whole (Hillesund 1994). Integrating the visual with the verbal affords new ways of looking at and interpreting media content (Barnhurst $\&$ Nerone 2001). In the present case we will be focusing on how pictures - stills and motion pictures - relate to texts, and how the relationships contribute to representations of the conversational (interview) situation (Sturken \& Cartwright 2001, van Leeuwen \& Jewitt 2001).

In order to secure continuity in the material, we have chosen four newspapers that extend over the entire period of study. These are the daily papers, Dagens Nyheter (DN) and Aftonbladet, and the dominant weekly magazines during the periods in question - for example, Illustrerad Familj-Journal (subsequently Allers), and Svensk Damtidning. DN and Aftonbladet quickly became two of the most 
widely read Swedish newspapers; they also attained national distribution at an early date. The two magazines represent two different traditions the family magazine and the women's magazine, respectively. Both are central in Swedish magazine journalism history, and both are close to the foci of our study, namely, the family and sexuality. By the time of our third period of study (see below) radio had established itself in Swedish households. Television was a fixture in many homes by the fourth period. We intend to apply different variants of thematic content analysis and discourse analysis in combination with feminist theory (see, for example, Diamond \& Quinby 1988, Smith 1990, Sawicki 1991, McNay 1992, Mills 1992, Caldas-Coulthard 1995, Hutchby \& Wooffitt 1998).

\section{Methodology}

An overarching assumption, which is also a prime motive for discourse analysis, is that verbal power relations correspond to real power relations; actors that dominate others in texts, dominate them in reality, as well. The principal task of discourse analysis is to examine such power relationships. The present research program has drawn inspiration from the discourse-historical perspective developed by Ruth Wodak $(1997,2001,2003)$ and others, particularly analyses of debates and political controversies. According to this perspective, text analysis must be combined with analyses of both the immediate context of the text (actors, the communication situation, and its cultural/political/economic framework) and the historical context of the events and subjects involved. With the help of a technique called recontextualization Wodak shows how a phenomenon, issue or concept can be assigned new meanings that alter textual and real power relationships, by being lifted over from one context to another. The technique reveals textual and visual strategies of dominance that are applied to maintain or create power relationships. Wodak's discourse-historical approach and its emphasis on social and historical contexts resembles the context-oriented method of discourse analysis that Jan Ekecrantz and Tom Olsson (1994) developed and applied to Swedish news journalism. Ekecrantz and Olsson are more interested in the institutional and discursive contexts of texts, and less in textual and visual structures.

Ekecrantz and Olsson's contextualization of journalistic texts in broader societal structures, including prevailing power relations between journalism and other institutions at different points in time, marks an important change in how media scholars view journalism. The shift or change we perceive may be described as both objectification and as fictionalization. Journalism is objectified in the sense that the researchers observe journalism from a distance, looking at it as an external object (in contrast to traditional press historical research, which tends to observe journalism "from within", judging it on its own merits with a great deal of deference to the conditions of production and other constraints). Journalism is fictionalized in the sense that its prime characteristic is no longer a mimetic relationship to reality; instead, researchers' interest rests on the ability of journalism to construct narratives about reality, irrespective of their basis in reality.

\section{Execution}

Taking account of historical changes in the practice of journalism and the successive increase in focus on social issues relating to the intimate sphere, we have identified a number of periods - selected points in time - of relevance to our topic.

We start with the years around 1885 and the decade in which modern mass journalism experienced a breakthrough in Sweden. The new opportunities to reach a large readership elicited changes in both the form and content of journalism. Both the interview and illustration were novelties in the press of this era. Dagens Nyheter, with a circulation of about 25,000, was Sweden's largest newspaper; magazine publishing (Illustrerad Familj-Journal) had just come onto the Swedish market.

Our second period comprises the years around 1925. A characteristic of newspaper journalism of this era was a willingness to provide a forum for spokespersons for other institutions. The courteous questions of journalists and lengthy responses to them filled pages. The 1920s saw relatively many changes, notably women's suffrage and greater acceptance of female sexuality.

Around 1935, photo-journalistic periodicals, such as Se and Folket $i$ Bild, came onto the market. Advances in the technology of photoreproduction permitted a new informality in the use of pictures, of elites and members of the general public alike. There were many new entries on the magazine market. Radio had also come on the air.

The next period we examine comprises the years around 1965. This was a period of economic downturn in the daily press, and many papers folded. The weekly press, too, experienced a decline in circulation. So-called men's magazines made their debut. Television had established itself faster than 
many had anticipated, and the television interview was something genuinely new.

Our fifth period comprises the years around 1980. Sweden now had two competing (non-commercial) television channels, both in the same public service company. A new style of television journalism was introduced that in retrospect may be seen as an early form of infotainment. Interviews, which were held in a more or less intimate conversational tone, had moved to the studio sofa, and guests were not necessarily the figures featured in newscasts.

The study ends in the present, with the years around 2000. Public service broadcasting - both radio and television - has been destabilized through the emergence of commercial competitors that, in the case of television, includes a large number of international channels. The diversity of output has brought a popularization of Swedish broadcasting in a posi- tive sense, whereby people and groups that previously were marginalized in the media (e.g., gays and ethnic minorities) have become visible. At the same time, the issue of media exploitation of these groups has also surfaced. We find an increasing symbiosis between the tabloid press and television programming, particularly in the case of newer television genres like docu-soaps and reality TV.

\section{Case Studies and Publications}

A number of case studies, of varying extent, are planned within the framework of The Intimization of Journalism. Specifics of the studies and the publication of findings within the program will be reported continuously on our website: www.jmk.su.se/ journintim.

\section{References}

Barnhurst, Kevin G. and John Nerone (2001) The Form of News. A History, New York: Guilford Press.

Benhabib, Seyla (1992) "Models of Public Space: Hannah Arendt, the Liberal Tradition, and Jürgen Habermas" in Calhoun, Craig (ed) Habermas and the Public Sphere, Boston: Massachusetts Institute of Technology.

Blumler, Jay G \& Michael Gurevitch (1995) The Crisis of Public Communication, London: Routledge.

Boling, Patricia (1996) Privacy and the politics of intimate life, Ithaca, N.Y.: Cornell University Press.

Caldas-Coulthard, Carmen (1995) "Man in the news: the misrepresentation of women speaking in newsas-narrative-discourse", in Mills, Sara (ed.), Language and Gender: Interdisciplinary Perspectives, Harlow: Longman.

Clayman, Steven E (2002) "Tribune of the People: Maintaining the Legitimacy of Aggressive Journalism" in Media, Culture \& Society vol. 24:2.

Dahlgren, Peter (1994) "Den offentliga sfären i kulturteoretisk belysning" [A cultural take on the public sphere] in Carlsson, Ulla (red) Kommunikationens korsningar, Göteborg: Nordicom.

Diamond, Irene \& Lee Quinby, eds. (1988) Foucault and Feminism: Reflections of Resistance, Boston: North Eastern University Press.

Ekecrantz, Jan \& Tom Olsson (1994) Det redigerade samhället, [The edited society] Stockholm: Carlssons.

Esser, Frank (1999) “'Tabloidization' of News. A Comparative Analysis of Anglo-American and German

Press Journalism", in European Journal of Communication, vol. 14:3.

Fraser, Nancy (1992) "Rethinking the Public Sphere: A Contribution to the Critique of Actually Existing Democracy" in Calhoun, Craig (ed.) Habermas and the Public Sphere, Cambridge: The MIT Press.

Fraser, Nancy (1995) "What's Critical about Critical Theory?" in Meehan, Johanna (ed), Feminists Read Habermas. Gendering the Subject of Discourse, London \& New York: Routledge.

Fraser, Nancy (1997) Justice Interruptus. Critical Reflections on the "Postsocialist" condition, New York \& London: Routledge

Gripsrud, Jostein (1999) Mediekultur, mediesamfunn, Oslo: Universitetsforlaget.(English translation, Understanding Media Culture, published in 2002.)

Habermas, Jürgen (1988) Borgerlig offentlighet, Lund: Arkiv. (Swedish translation of Strukturwandel der Öffentlichkeit.)

Halonen, Irma Kaarina (1990) "Kvinnor och offentlighet" [Women and the public sphere] in Carlsson, Ulla (red) Medier Människor Samhälle, Göteborg: Nordicom.

Hartley, John (1996) Popular Reality: Journalism, Modernity, Popular Culture. London, New York: Arnold.

Hillesund, Terje (1994) Står det noe nytt? [Anything new?], Oslo: Institutt for Journalistikk.

Hirdman, Anja (1994) “Den heliga elden”. Synen på de prostituerade $i$ statliga utredningar mellan 1903 och 1962, ["The sacred flame". Perceptions of prostitutes] C-uppsats, Stockholms universitet, Avdelningen för idéhistoria. 
Hirdman, Anja (2000) "Male norms and female forms", in Becker, Karin m fl (eds.), Picturing Politics, Stockholm: JMK.

Hirdman, Anja (2002) Tilltalande bilder. Genus, sexualitet och publiksyn i Veckorevyn och Fib aktuellt. [Alluring Images. Gender, Sexuality and Modes of Address in Veckorevyn and Fib aktuellt] Atlas: Stockholm

Holland, Patricia (1998) "The politics of the smile: 'Soft news' and the sexualization of the popular press", in Carter, Cynthia et al (eds.), News, Gender and Power, London: Routledge.

Hutchby, Ian \& Robert Wooffitt (1998) Conversation Analysis: Principles, Practices and Applications, Oxford: Polity Press.

Kleberg, Madeleine (1987) "Kvinnor och nyheter. Förenklad teori i praktiken" [Simplistic theory in practice] in Kvinnovetenskaplig Tidskrift, nummer 3 1988.

Kleberg, Madeleine \& Kristina Widestedt (2002) "Ledare i blåsväder - mediernas privatisering av kvinnor" [Public figures in hot water - a study of the media's privatization of women] in Hvitfelt, Håkan och Lauri Karvonen (red), Den personliga politiken, Sundsvall: Demokratiinstitutet.

Landes, Joan B. (1998) "The Public and the Private Sphere: A Feminist Reconsideration" in Landes, Joan B. (ed), Feminism, the Public and the Private, Oxford: Oxford University Press.

Lennerhed, Lena (1994) Frihet att njuta. Sexualdebatten i Sverige på 1960-talet [The Pursuit of Pleasure. The Sex-Debate in Sweden during the 60's], Stockholm: Norstedts.

Livingstone, Sonia \& Peter Lunt (1994) Talk on Television, London: Routledge.

McLaughlin, Lisa (1998) "Gender, privacy and publicity in 'media event space'", in Carter, Cynthia et al (eds), News, Gender and Power, London: Routledge.

McNay, Lois (1992) Foucault and Feminism, Oxford: Polity Press.

Mills, Sara (1992) "Discourse competence: or how to theorise strong women speakers", in Hypatia, vol. 7 no. 2 .

Pateman, Carole (1988) The Sexual Contract, Stanford: Stanford U.P.
Sawicki, Jana (1991) Disciplining Foucault: Feminism, Power and the Body, London/New York: Routledge.

Schiller, Dan (1981) Objectivity and the News: The Public and the Rise of Commercial Journalism, Philadelphia: University of Pennsylvania Press.

Schudson, Michael (1994) "Question Authority: A History of the News Interview", in Media, Culture \& Society vol. 16

Smith, Dorothy (1990) Texts, Facts and Femininity: Exploring the Relations of Ruling, London: Routledge.

Sparks, Colin (2000) "Introduction: The panic over tabloid news", in Sparks, Colin \& John Tulloch, eds., (2000) Tabloid Tales: Global Debates over Media Standards, Lanham: Rowman \& Littlefield.

Sparks, Colin \& John Tulloch, eds., (2000) Tabloid Tales: Global Debates over Media Standards, Lanham: Rowman \& Littlefield.

Sturken, Marita \& Lisa Cartwright (2001) Practices of Looking, Oxford/New York: Oxford University Press.

Svanström, Yvonne (2000) Policing Public Women. The Regulation of Prostitution in Stockholm 18121880, Stockholm: Atlas.

Söderblom, Tomas (1992) Horan och batongen: prostitution och repression i folkhemmet [Prostitution and oppression in the nascent welfare state], Stockholm: Gidlund.

Thompson, John B. (1995) The Media and Modernity. A Social Theory of the Media, Oxford: Polity Press.

van Leeuwen, Theo \& Carey Jewitt (2001) Handbook of Visual Analysis, London: SAGE.

Weiss, Gilbert \& Ruth Wodak, eds. (2003) Critical discourse analysis: theory and interdisciplinarity, Basingstoke/New York: Palgrave Macmillan.

Wendt Höjer, Maria (2002) Rädslans politik. Våld och sexualitet $i$ den svenska demokratin [The Politics of Fear. Violence and Sexuality and Swedish Democracy], Lund: Liber.

Wodak, Ruth, ed. (1997) Gender and discourse, London: Sage.

Wodak, Ruth \& Michael Meyer, eds. (2001) Methods of critical discourse analysis, London: SAGE. 